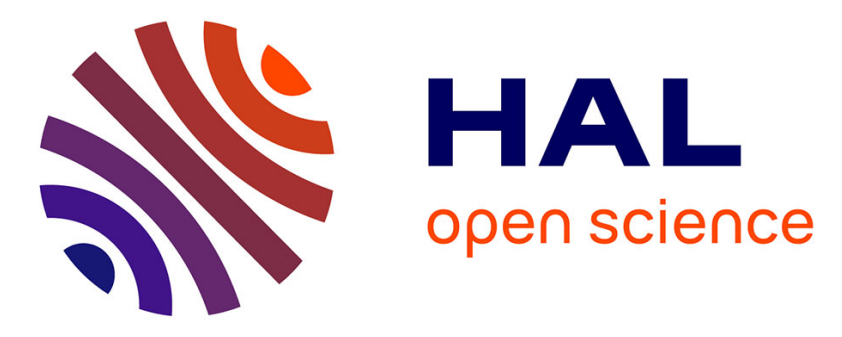

\title{
Acid DNases and their interest among apoptotic endonucleases.
}

Marie-France Counis, Alicia Torriglia

\section{To cite this version:}

Marie-France Counis, Alicia Torriglia. Acid DNases and their interest among apoptotic endonucleases.. Biochimie, 2006, 88 (12), pp.1851-8. 10.1016/j.biochi.2006.07.008 . inserm-00129402

\section{HAL Id: inserm-00129402 https://www.hal.inserm.fr/inserm-00129402}

Submitted on 7 Feb 2007

HAL is a multi-disciplinary open access archive for the deposit and dissemination of scientific research documents, whether they are published or not. The documents may come from teaching and research institutions in France or abroad, or from public or private research centers.
L'archive ouverte pluridisciplinaire HAL, est destinée au dépôt et à la diffusion de documents scientifiques de niveau recherche, publiés ou non, émanant des établissements d'enseignement et de recherche français ou étrangers, des laboratoires publics ou privés. 

虽总
(D)
$\stackrel{0}{<}$

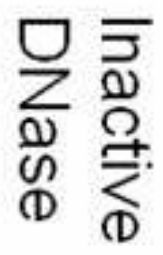
(D)

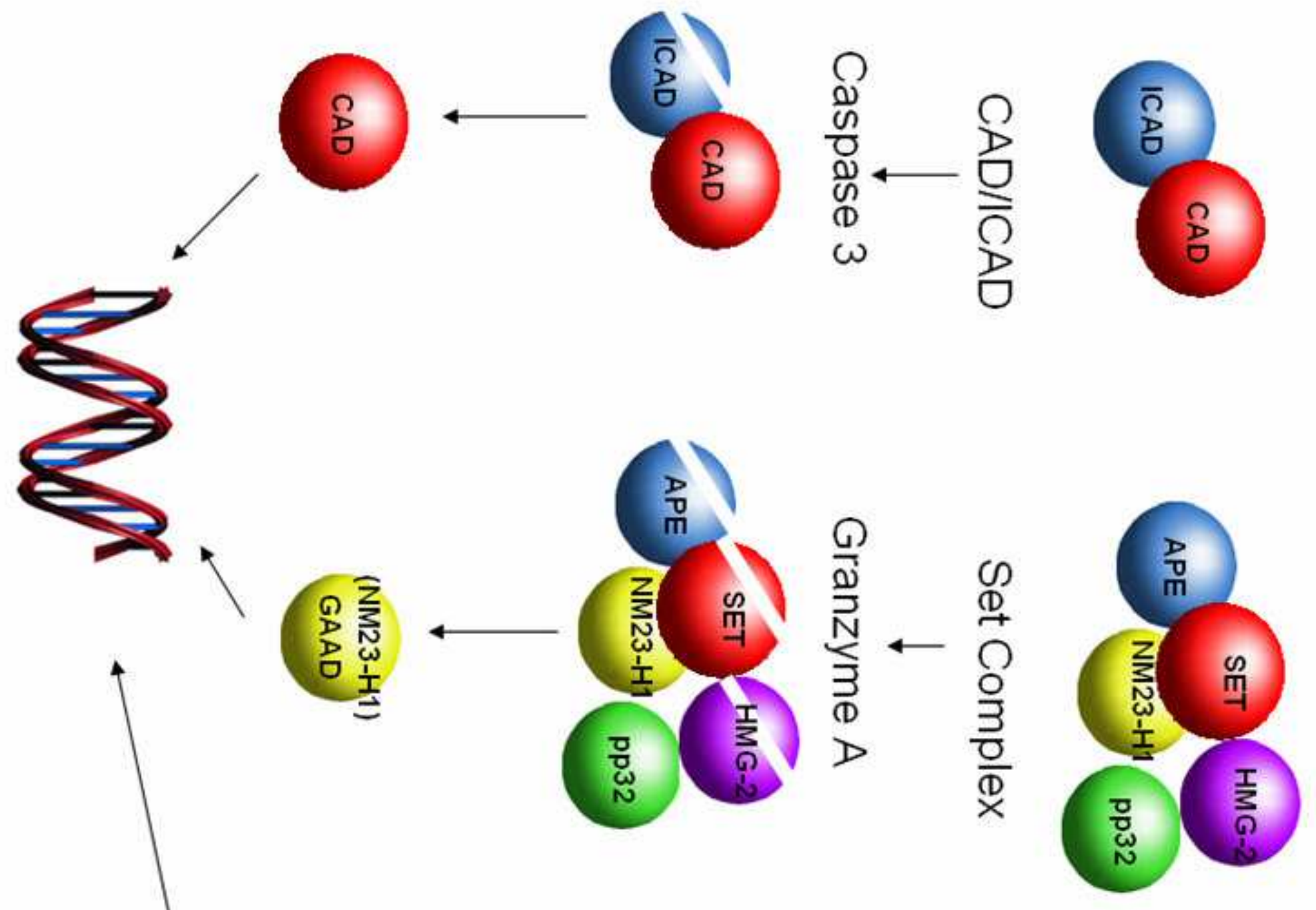

